\title{
Vital Signs Clinical Significance
}

National Cancer Institute

\section{Source}

National Cancer Institute. Vital Signs Clinical Significance. NCI Thesaurus. Code C83022.

An indication or description that the outcome of the vital signs assessment was clinically significant. 